\title{
BASIC FIBROBLAST GROWTH FACTOR STIMULATES PHOSPHORYLATION OF CCAAT/ENHANCER-BINDING PROTEIN $\delta$ BY ACTIVATION OF MITOGEN-ACTIVATED PROTEIN KINASE
}

\author{
Hiroshi Kimura ${ }^{1,2}$, Kohj Fukunaga ${ }^{1}$, Yukitaka Ushio ${ }^{2}$ and Eishichi Miyamoto ${ }^{1,3}$ \\ 'Departments of Pharmacology and ${ }^{2}$ Neurosurgery, Kumamoto University School of Medicine, Kumamoto 860-0811, Japan
}

\begin{abstract}
Stimulation of cultured astrocytes with basic fibroblast growth factor (bFGF) increased phosphorylation of CCAAT/enhancer-binding protein (C/EBP) $\delta$, but not C/EBP $\beta$. The maximal phosphorylation was obtained $60 \mathrm{~min}$ after stimulation. PD098059, a specific inhibitor of mitogen-activated protein kinase kinase (MAP kinase kinase), inhibited phosphorylation of $\mathrm{C} / \mathrm{EBP} \delta$. Immunohistochemistry showed that bFGF stimulation of cultured astrocytes induced the translocation of activated MAP kinase from the cytoplasm to the nucleus and surrounding regions. This translocation was inhibited by addition of PD098059. Dibutyryl cyclic AMP (dbcAMP) increased the total amount of C/EBP $\delta$ protein but had no effect on its phosphorylation state. KN93, a specific inhibitor of $\mathrm{Ca}^{2+} /$ calmodulin-dependent protein kinase II, and calphostin $\mathrm{C}$, a specific inhibitor of protein kinase $\mathrm{C}$, did not inhibit phosphorylation of $\mathrm{C} / \mathrm{EBP} \delta$ following stimulation with bFGF. Gel mobility shift analysis using nuclear extracts from bFGF-treated cells showed increases in C/EBP site binding activities $60 \mathrm{~min}$ after stimulation with bFGF. These results suggest that bFGF stimulates phosphorylation of $\mathrm{C} / \mathrm{EBP} \delta$ through activation of MAP kinase, and is involved in stimulation of gene expression by phosphorylation of $\mathrm{C} / \mathrm{EBP} \delta$.
\end{abstract}

The CCAAT/enhancer-binding protein (C/EBP) family members are transcription factors belonging to a class of basic region-leucine zipper proteins $(29,50,56)$. The C/EBP family consists of at least six members, including C/EBP $\alpha(30), \beta(1,14$, $39,53), \gamma(43), \delta(24,25,53), \varepsilon(53)$ and CHOP10 (44). Functions of members of the C/EBP family have been extensively studied in liver cell nuclei; some $\mathrm{C} / \mathrm{EBP}$ proteins are involved in

\footnotetext{
Abbreviations: bFGF, basic fibroblast growth factor; $\mathrm{C} / \mathrm{EBP}, \mathrm{CCAAT/enhancer-binding} \mathrm{protein;} \mathrm{CaM} \mathrm{kinase}$ II, $\mathrm{Ca}^{2+} /$ calmodulin-dependent protein kinase II; cAMP, cyclic AMP; dbcAMP, dibutyryl cyclic AMP; KRH, Krebs-Ringer HEPES; MAP kinase, mitogen-activated protein kinase; SDS-PAGE, sodium dodecyl sulfatepolyacrylamide gel electrophoresis; TBS, Tris-buffered saline; MEK, mitogen-activated protein kinase kinase ${ }^{3}$ Correspondence to: E. Miyamoto at the above address. Tel: 81-96-373-5076; Fax: 81-96-373-5078
}

expression of acute phase genes induced by mediators of inflammation $(2,9,10,14,39,41,42)$. In $\mathrm{PC} 12$ cells, expression of the c-fos gene is regulated by $\mathrm{C} / \mathrm{EBP} \beta$ (33), and the $\mathrm{C} / \mathrm{EBP}$ family is involved in differentiation and proliferaion of the cells (56). The transcriptional activity of $\mathrm{C} / \mathrm{EBP} \beta$ was reported to be increased by phosphorylation $(11,31,34,35,47-49,52)$.

We have reported that stimulation of cultured astrocytes with glutamate activates $\mathrm{Ca}^{2+} /$ calmodulin-dependent protein kinase II (CaM kinase II) with concomitant phosphorylation of cytoskeletal proteins $(12,17,37,55)$. Furthermore, both $\mathrm{C} / \mathrm{EBP} \beta$ and $\mathrm{C} / \mathrm{EBP} \delta$ but not $\mathrm{C} / \mathrm{EBP} \alpha$ are expressed in astrocytes $(8,17,54)$. After exposure to glutamate, C/EBP $\beta$ mRNA levels increased within $10 \mathrm{~min}$, while $\mathrm{C} / \mathrm{EBP} \delta$ mRNA levels decreased by $6 \mathrm{~h}$. In astrocytes, glutamate stimulation resulted in phosphorylation of $\mathrm{C} / \mathrm{EBP} \beta$, most likely by CaM kinase II (54). Stimulation of astrocytes 
with glutamate increased the DNA-binding activities of C/EBP $\beta$ and $\delta(54)$.

Basic fibroblast growth factor (bFGF) is a member of a family of heparin-binding growth factors which activate a receptor tyrosine kinase $(21,46)$. In the brain, bFGF has important roles in development and regeneration of tissue $(5,20,38,51)$. It has a broad action on both glial $(20,38)$ and neuronal cells (51) and is involved in brain repair following traumatic injury (15). It was recently reported that C/EBP family members are immediate early genes required for the consolidation of long-term facilitation in Aplysia (3).

Growth factors including bFGF activate mitogen-activated protein kinase (MAP kinase) via activation of receptor tyrosine kinases in various cells $(6,13,22,23,26,28,45)$. We reported that bFGF activates MAP kinase in association with an increase in DNA synthesis in astrocytes (27).

The present study shows that stimulation of astrocytes with $\mathrm{bFGF}$ phosphorylates $\mathrm{C} / \mathrm{EBP} \delta$, but not C/EBP $\beta$ by activation of MAP kinase.

\section{MATERIALS AND METHODS}

\section{Materials}

The following chemicals and reagents were obtained from the indicated sources: fetal calf serum, JRH Biosciences; [ $\left.{ }^{32} \mathrm{P}\right]$ orthophosphate, ICN Biochemicals; $\left[\gamma^{-32}\right.$ P]ATP, DuPont NEN; L-glutamate, basic fibroblast growth factor (bFGF) and dibutyryl cAMP (dbcAMP), Sigma; Hanks' balanced salts, Life Technologies; calphostin C, Kyowa Medex; protein A-Sepharose CL-4B, Pharmacia Fine Chemicals; Eagle's minimal essential medium, Nissui Pharmaceutical; anti-C/EBP $\beta$ antibody and anti-C/EBP $\delta$ antibody, Santa Cruz Biotechnology; PD098059, Research Biochemicals International; KN93, Seikagaku Kogyo; anti-active MAP kinase antibody, Promega; fluorescein-conjugated goat affinity-purified antibody to rabbit IgG, ICN Pharmaceuticals.

\section{Cell Culture}

Cultured astrocytes were prepared from the neocortices of 1-day-old Wistar rats, as described previously (55). The brain cortices from 1-day-old rats were mechanically dissociated by trituration with fire-polished Pasteur pipettes and plated in $80-\mathrm{cm}^{2}$ flasks in growth medium. The growth medium consisted of $45 \%$ Eagle's minimum essential medium, $45 \%$ Hanks' balanced salt solution and $10 \%$ fetal calf serum. The cultures were maintained at $37^{\circ} \mathrm{C}$ in a water-saturated atmosphere of $95 \%$ air and $5 \%$ $\mathrm{CO}_{2}$, with the medium replaced twice a week. After 1 week, contaminating cells were removed by orbital shaking (32). The astrocytes were subcultured in $35-\mathrm{mm}, 60-\mathrm{mm}$ or $100-\mathrm{mm}$ dishes coated with poly-L-lysine and maintained for at least 5 days before use. Astrocytes were almost flat and polygonal and were classified as type 1 astrocytes (40). Neurons were never observed in subcultured cells.

\section{Labeling of Cells and Phosphorylation of $C / E B P \beta$, and $C / E B P \delta$ in Astrocytes}

Cultured astrocytes were grown to confluency and incubated in serum-free medium for $24 \mathrm{~h}$. The astrocytes in 60-mm dishes were washed once with phosphate-free and serum-free minimum essential medium and labeled in $2.0 \mathrm{ml}$ of the medium containing carrier-free $\left[{ }^{32} \mathrm{P}\right]$ orthophosphate $(0.25 \mathrm{mCi} / \mathrm{ml})$, as described previously (18). After labeling for $5 \mathrm{~h}$, the cells were preincubated in Krebs-Ringer HEPES buffer (KRH) containing $128 \mathrm{mM} \mathrm{NaCl}, 5 \mathrm{mM} \mathrm{KCl}, 1 \mathrm{mM}$ sodium phosphate, $1.2 \mathrm{mM} \mathrm{MgSO}_{4}, 10 \mathrm{mM}$ glucose, $2.7 \mathrm{mM} \mathrm{CaCl}$, and $20 \mathrm{mM}$ HEPES (pH 7.4), at $37^{\circ} \mathrm{C}$ for $15 \mathrm{~min}$. After preincubation, the cells were incubated without (control) or with bFGF $(100 \mathrm{ng} / \mathrm{ml})$ for the indicated times. In assays requiring inhibitors, cells were preincubated in $\mathrm{KRH}$ or an inhibitor in $\mathrm{KRH}$ at $37^{\circ} \mathrm{C}$ for $15 \mathrm{~min}$. After preincubation, the cells were incubated without (control) or with bFGF $(100 \mathrm{ng} / \mathrm{ml})$, an inhibitor or bFGF plus each inhibitor for $60 \mathrm{~min}$. Stimulation of cells was terminated by aspiration of the medium, and the cells were immediately frozen in liquid $\mathrm{N}_{2}$. Frozen astrocytes were scraped from a $60-\mathrm{mm}$ dish and homogenized with $0.9 \mathrm{ml}$ of a buffer containing $50 \mathrm{mM}$ HEPES, $0.1 \%$ Triton X-100, $4 \mathrm{mM}$ EGTA, $10 \mathrm{mM}$ EDTA, $15 \mathrm{mM} \mathrm{Na} \mathrm{P}_{2} \mathrm{O}_{7}, 100 \mathrm{mM} \beta$-glycerophosphate, 25 $\mathrm{mM} \mathrm{NaF}, 0.4 \mathrm{M} \mathrm{NaCl}, 50 \mu \mathrm{g} / \mathrm{ml}$ leupeptin, 50 $\mu \mathrm{g} / \mathrm{ml}$ trypsin inhibitor, and $25 \mu \mathrm{g} / \mathrm{ml}$ pepstatin A. Triton X-100-soluble fractions were then subjected to immunoprecipitation with the anti-C/EBP $\beta$ antibody $(5 \mu \mathrm{g})$ plus $50 \mu \mathrm{l}$ of protein A-Sepharose CL$4 \mathrm{~B}(50 \%, \mathrm{v} / \mathrm{v})$ or the anti-C/EBP $\delta$ antibody $(5 \mu \mathrm{g})$ plus $50 \mu \mathrm{l}$ of protein A-Sepharose CL-4B (50\%, $\mathrm{v} / \mathrm{v}$ ) at $4^{\circ} \mathrm{C}$ overnight, as previously described (19). The immunocomplex immobilized on protein ASepharose CL-4B was washed three times with homogenization buffer. Each immunoprecipitate 
was eluted from protein A Sepharose CL-4B by boiling in SDS sample buffer for $4 \mathrm{~min}$. Supernatants were further subjected to SDS-PAGE in $12 \%$ acrylamide, followed by autoradiography. A Bio-Imaging analyzer (model BA100) was used to quantify the amounts of ${ }^{32} \mathrm{P}$-incorporation into $\mathrm{C} / \mathrm{EBP} \beta$ or $\mathrm{C} / \mathrm{EBP} \delta$.

\section{Indirect Immunofluorescence Analysis}

Astrocytes cultured in 35-mm dishes were incubated in serum-free medium for $24 \mathrm{~h}$. The cells were preincubated in $\mathrm{KRH}$ at $37^{\circ} \mathrm{C}$ for $15 \mathrm{~min}$, or preincubated with $50 \mu \mathrm{M}$ PD098059 in KRH for 50 min. After preincubation, the cells were incubated without (control) or with bFGF $(100 \mathrm{ng} / \mathrm{ml})$ or bFGF plus PD098059 for $60 \mathrm{~min}$. Incubation of cells was terminated by aspiration of the medium. The cells were washed with phosphate-buffered saline (PBS) and fixed at $-20^{\circ} \mathrm{C}$ for $10 \mathrm{~min}$ with cold methanol. After a 10-min dehydration at room temperature, the cells were treated with $0.01 \%$ Triton X-100 in PBS for permeabilization. Nonspecific antibody binding was blocked by preincubation with 5\% goat serum in PBS (blocking solution), followed by incubation overnight with the antiactive MAP kinase antibody in the blocking solution at a 50-fold dilution. The cells were then washed five times with PBS and incubated for 60 min with a fluorescein-conjugated goat affinitypurified antibody to rabbit IgG in PBS containing $0.01 \%$ Triton X-100. Finally, the cells were washed with PBS, and mounted in Tris-buffered saline (TBS) containing 50\% (v/v) glycerol, 0.15 $\mathrm{M} \mathrm{NaCl}$ and $20 \mathrm{mM}$ Tris- $\mathrm{HCl}$ (pH 7.4). The cells were observed and photographed with a FLUOVIEW BX50 (Olympus).

\section{Immunoblotting}

Cultured astrocytes were grown to confluency and incubated in serum-free medium for $24 \mathrm{~h}$. Astrocytes in 100-mm dishes were preincubated in KRH or dbcAMP $(1 \mathrm{mM})$ in $\mathrm{KRH}$ for $15 \mathrm{~min}$. After preincubation, the cells were incubated without (control) or with bFGF $(100 \mathrm{ng} / \mathrm{ml})$, dbcAMP (1 $\mathrm{mM}$ ) or bFGF plus dbcAMP for $60 \mathrm{~min}$. Stimulated astrocytes were washed twice with the cold buffer containing $0.15 \mathrm{M} \mathrm{NaCl}, 1.5 \mathrm{mM} \mathrm{KH}_{2} \mathrm{PO}_{4}, 3$ $\mathrm{mM} \mathrm{KCl}, \quad 10 \mathrm{mM} \quad \mathrm{Na}_{2} \mathrm{HPO}_{4} \cdot 12 \mathrm{H}_{2} \mathrm{O}, \quad 0.5 \mathrm{mM}$ EDTA, scraped with $1 \mathrm{ml}$ of the same buffer at $0^{\circ} \mathrm{C}$, collected from the dish, and centrifuged at $2,500 \times g$ for $5 \mathrm{~min}$. The pellets were homog- enized with $0.1 \mathrm{ml}$ of a buffer containing $50 \mathrm{mM}$ HEPES, $0.1 \%$ Triton X-100, $4 \mathrm{mM}$ EGTA, $10 \mathrm{mM}$ EDTA, $15 \mathrm{mM} \mathrm{Na}_{4} \mathrm{P}_{2} \mathrm{O}_{7}, 100 \mathrm{mM} \beta$-glycerophosphate, $25 \mathrm{mM} \mathrm{NaF}, 0.4 \mathrm{M} \mathrm{NaCl}, 50 \mu \mathrm{g} / \mathrm{ml} \mathrm{leu}-$ peptin, $50 \mu \mathrm{g} / \mathrm{ml}$ trypsin inhibitor, and $25 \mu \mathrm{g} / \mathrm{ml}$ pepstatin A. Triton X-100-soluble fractions were incubated for $15 \mathrm{~min}$ on ice and centrifuged at $15,000 \times g$ for $10 \mathrm{~min}$. Aliquots of supernatants were assayed for protein concentration, and the same amount of protein $(25 \mu \mathrm{g})$ was subjected to SDS-PAGE in $12 \%$ acrylamide and transferred electrophoretically to a nitrocellulose membrane at $60 \mathrm{~V}$ for $3 \mathrm{~h}$. After the membrane was incubated at $4^{\circ} \mathrm{C}$ for $1 \mathrm{~h}$ with $4.5 \%$ skim milk in TBS (pH 7.4) to block nonspecific binding sites, it was incubated with antibodies overnight, as previously described (55). The anti-C/EBP $\beta$ and anti-C/EBP $\delta$ antibodies were diluted $1: 100$ in TBS containing $2.5 \%$ BSA. Immunoreactive peptides were detected using ${ }^{125} \mathrm{I}$ labeled protein $\mathrm{A}$.

\section{Preparation of Nuclear Extracts and Gel Mobility Shift Assay}

Cultured astrocytes were grown to confluency and incubated in serum-free medium for $24 \mathrm{~h}$. Astrocytes in 100-mm dishes were preincubated in KRH or PD098059 $(50 \mu \mathrm{M})$ in KRH for $15 \mathrm{~min}$. After preincubation, the cells were incubated without (control) or with bFGF $(100 \mathrm{ng} / \mathrm{ml})$ or bFGF plus PD098059 for $60 \mathrm{~min}$. The cells were washed twice, homogenized in cold TBS, and centrifuged at $1,500 \times g$ for $15 \mathrm{~min}$. The pellets were resuspended in TBS and centrifuged at $15,000 \times g$ for $15 \mathrm{~s}$. The pellets were resuspended in $400 \mu 1$ of the buffer containing $10 \mathrm{mM}$ HEPES (pH 7.9), $10 \mathrm{mM}$ $\mathrm{KCl}, 0.1 \mathrm{mM}$ EDTA, $0.1 \mathrm{mM}$ EGTA, $1 \mathrm{mM}$ DTT, $0.5 \mathrm{mM}$ PMSF, and allowed to swell on ice for 15 min. Then $25 \mu \mathrm{l}$ of $10 \%$ NP-40 was added, and the suspension was vigorously vortexed for $10 \mathrm{~s}$ and centrifuged for $30 \mathrm{~s}$. The pellets were resuspended in $50 \mu \mathrm{l}$ of the buffer containing $20 \mathrm{mM}$ HEPES (pH 7.9), 0.4 M NaCl, 1 mM EDTA, 1 mM EGTA, $1 \mathrm{mM}$ DTT and $1 \mathrm{mM}$ PMSF, allowed to swell on ice $10 \mathrm{~min}$ and centrifuged for $5 \mathrm{~min}$. The supernatants were used for a gel mobility shift assay as nuclear extracts. The probe used in gel-shift assays was the double-stranded oligonucleotide corresponding to the CaM kinase II-responsive element (CaMRE) of the Rous sarcoma virus long terminal repeat promoter (Rous sarcoma virus nucleotides -231 to $-193 ; 5^{\prime}$-AAATGTAGTCTTATGCAATACACTTGTAGTCTTGCAACA- $3^{\prime}$ ). This sequence 
constitutes a binding site for C/EBP (52). The $5^{\prime}$ ends of probe DNAs were labeled with $\left[\gamma^{32} \mathrm{P}\right]$ ATP by T4 polynucleotide kinase. The standard binding reaction was carried out in $10 \mu \mathrm{l}$ of a mixture containing $25 \mathrm{mM}$ HEPES (pH 7.6), $50 \mathrm{mM}$ $\mathrm{KCl}, 1 \mathrm{mM}$ EDTA, $0.5 \mathrm{mM}$ spermidine, $0.6 \mathrm{mM}$ dithiothreitol, $12 \%$ glycerol, $5 \mu \mathrm{g}$ of poly(dI-dC), 1 fmol of the ${ }^{32} \mathrm{P}$-labeled probe (about $2 \times 10^{4} \mathrm{dpm}$ ), and nuclear extracts (3-4 $\mu \mathrm{g}$ of protein). In competition analysis, 1 pmol of the competitor oligonucleotide was mixed before the addition of nuclear extracts. After $30 \mathrm{~min}$ on ice, $2.5 \mu \mathrm{l}$ of $20 \%$ Ficoll were added, and the samples were loaded onto a $5 \%$ polyacrylamide gel in a buffer containing 89 $\mathrm{mM}$ Tris, $89 \mathrm{mM}$ boric acid, and $2.5 \mathrm{mM}$ EDTA. Electrophoresis was performed at $10 \mathrm{~V} / \mathrm{cm}$ for $2 \mathrm{~h}$ at room temperature. The gel was then dried and autoradiographed on X-ray films at $-80^{\circ} \mathrm{C}$. For antibody double shift analysis, $3 \mu \mathrm{g}$ of the anti$\mathrm{C} / \mathrm{EBP} \beta$ or the anti-C/EBP $\delta$ antibody was added to mixtures of the binding reaction for the last 15 $\min$.

\section{Other Methods}

Protein concentration was determined by the method of Bradford (7) with bovine serum albumin as the standard.

\section{Statistical Evaluation}

Values are means $\pm S E$. The significance of the difference between values was calculated by Student's $t$ test, and $p$ values of $<0.05$ were considered statistically significant.

\section{RESULTS AND DISCUSSION}

Phosphorylation of $C / E B P \beta$ and $C / E B P \delta$ by Stimulation with bFGF in Cultured Astrocytes

Phosphorylation of $\mathrm{C} / \mathrm{EBP} \beta$ and $\mathrm{C} / \mathrm{EBP} \delta$ following bFGF stimulation of astrocytes was examined in a time course (Fig. 1). During the time period examined, phosphorylation of C/EBP $\delta$ increased, while phosphorylation of $\mathrm{C} / \mathrm{EBP} \beta$ remained unchanged. Consistent with previous findings, $\mathrm{C} / \mathrm{EBP} \delta$ migrated at approximately $33 \mathrm{kDa}(8,11,54)$. Also observed were bands of 42 and $44 \mathrm{kDa}$, which may represent unrelated proteins cross-reacting with C/EBP antibody (11). Phosphorylation of C/EBP $\delta$ maximally increased by approximately $64 \% 60 \mathrm{~min}$ after stimulation and decreased by $120 \mathrm{~min}$. Increase in phosphorylation was not observed as

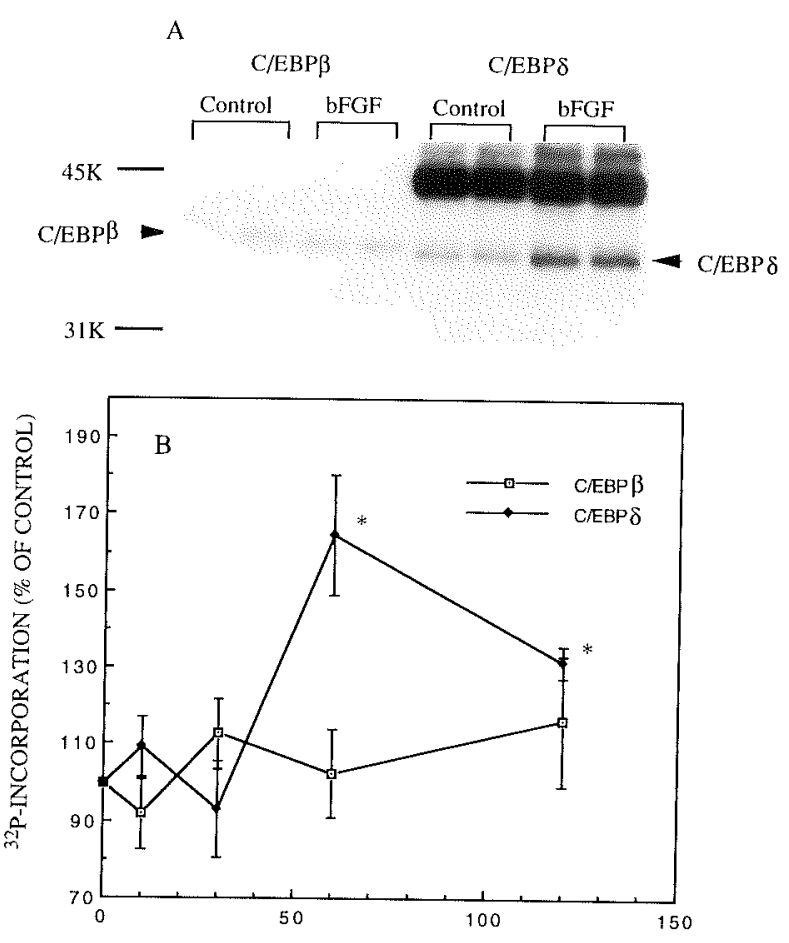

Fig. 1 Effects of bFGF on phosphorylation of C/EBP $\beta$ and $\mathrm{C} / \mathrm{EBP} \delta$ in cultured astrocytes during a time course. Cultured astrocytes were incubated in serum-free medium for $24 \mathrm{~h}$. After cells were labeled with $\left.{ }^{32} \mathrm{P}\right]$ orthophosphate $(0.25 \mathrm{mCi} / \mathrm{ml})$ for $5 \mathrm{~h}$, then were incubated in $\mathrm{KRH}$ for $15 \mathrm{~min}$ and stimulated without (control) or with bFGF $(100 \mathrm{ng} / \mathrm{ml})$. Immediately after the medium was aspirated at indicated times, the cells were frozen in liquid $\mathrm{N}_{2}$. The cells were then scraped and homogenized with buffer. Triton X-100-soluble fractions were subjected to immunoprecipitation with anti-C/EBP $\beta$ or anti-C/EBP $\delta$ antibody. A: After $60 \mathrm{~min}$ of stimulation, phosphorylated $\mathrm{C} / \mathrm{EBP} \beta$ and $\mathrm{C} / \mathrm{EBP} \delta$ were immunoprecipitated with the anti-C/EBP $\beta$ antibody $(5 \mu \mathrm{g})$ or the anti-C/EBP $\delta$ antibody $(5 \mu \mathrm{g})$ and were analyzed by SDS-PAGE, followed by autoradiography. $B$ : The time course of phosphorylation of $\mathrm{C} / \mathrm{EBP} \beta$ or $\mathrm{C} / \mathrm{EBP} \delta$ following stimulation with bFGF. The radioactivity was quantified by a Bio-Imaging analyzer BA100 (Fuji Photo Film, Japan) and expressed as a percentage of control. Values are means \pm SE. The increase in phosphorylation of C/EBP $\delta$ at $60 \mathrm{~min}$ and 120 min were statistically significant versus control $(\mathrm{n}=$ 5). ${ }^{*}, P<0.05$, versus the control

late as $30 \mathrm{~min}$ after stimulation. This observation suggests that it is unlikely that protein kinase $C$, cAMP-kinase or CaM kinase II is involved in phosphorylation, since phosphorylation of $\mathrm{C} / \mathrm{EBP} \beta$ by $\mathrm{CaM}$ kinase II increases within $5 \mathrm{~min}$ of stimulation $(16,17,54,55)$. 

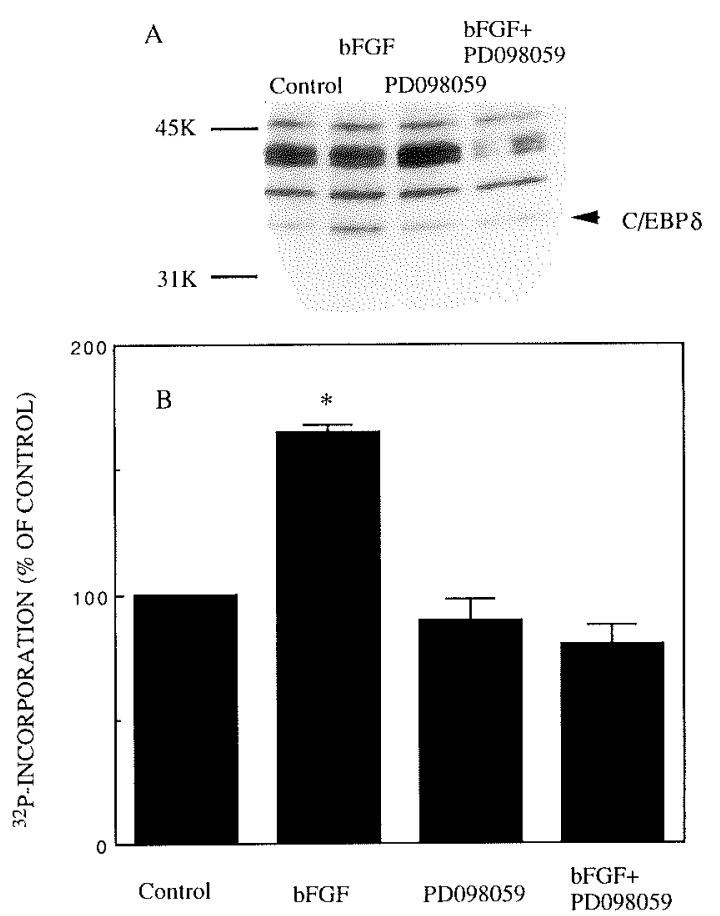

Fig. 2 Effect of MEK inhibitor PD098059 on bFGFstimulated phosphorylation of $\mathrm{C} / \mathrm{EBP} \delta$ in cultured astrocytes. Cultured astrocytes were incubated in serum-free medium for $24 \mathrm{~h}$ and labeled with $\left[{ }^{32} \mathrm{P}\right]$ orthophosphate $(0.25 \mathrm{mCi} / \mathrm{ml})$ for $5 \mathrm{~h}$ as in Fig. 1. The cells were preincubated without or with PD098059 $(50 \mu \mathrm{M})$ in $\mathrm{KRH}$ for $15 \mathrm{~min}$, and incubated without (control) or with bFGF $(100 \mathrm{ng} / \mathrm{ml}), \quad$ PD098059 $(50 \mu \mathrm{M})$ or bFGF plus PD098059 for $60 \mathrm{~min}$. After incubation, the medium was aspirated and the cells were frozen in liquid $\mathrm{N}_{2}$. The cells were then scraped and homogenized with buffer. Triton X-100-soluble fractions were subjected to immunoprecipitation with the anti-C/EBP $\delta$ antibody. A: Phosphorylated $\mathrm{C} / \mathrm{EBP} \delta$ was immunoprecipitated with the anti-C/EBP $\delta$ antibody $(5 \mu \mathrm{g})$ and analyzed by SDSPAGE, followed by autoradiography. B: ${ }^{32} \mathrm{P}$-incorporation into $\mathrm{C} / \mathrm{EBP} \delta$ was determined by a Bio-Imaging analyzer (model BA100) and expressed as a percentage of control. Values are means $\pm \mathrm{SE}(\mathrm{n}=3)$. ${ }^{*}, P<0.05$, versus the control

Effects of glutamate on phosphorylation of $\mathrm{C} / \mathrm{EBP} \beta$ and $\mathrm{C} / \mathrm{EBP} \delta$ were examined in astrocytes during a time course. In contrast to the results with bFGF, glutamate stimulated phosphorylation of $\mathrm{C} / \mathrm{EBP} \beta$, as previously reported $(17,54)$, but not of $\mathrm{C} / \mathrm{EBP} \delta$ in the 120 -min time period. Maximal phosphorylation of $\mathrm{C} / \mathrm{EBP} \beta$ following stimulation with $500 \mu \mathrm{M}$ glutamate was observed in $5 \mathrm{mim}$, with an approximately $45 \%$ increase over the control (54).
Effects of a MAP Kinase Kinase Inhibitor on Phosphorylation of $C / E B P \delta$ by Stimulation with $b F G F$

Phosphorylation of C/EBP $\delta$ by stimulation with bFGF suggests that MAP kinase may be involved in its phosphorylation, because the bFGF receptor contains an intracellular tyrosine kinase domain and stimulation of the receptor induces activation of the MAP kinase cascade $(13,22,23,26-28)$. Furthermore, the time course of phosphorylation is sustained for a relatively longer period compared to second messenger-dependent protein kinases such as protein kinase C, cAMP-kinase and CaM kinase II.

PD098059, a specific inhibitor of mitogen-activated protein kinase kinase or extracellular signalregulated kinase kinase (MEK) $(4,36)$, inhibited stimulation of C/EBP $\delta$ phosphorylation by bFGF (Fig. 2). PD098059 by itself had no effect on phosphorylation of $\mathrm{C} / \mathrm{EBP} \delta$. These results suggest that MAP kinase phosphorylates $\mathrm{C} / \mathrm{EBP} \delta$.

\section{Effects of a MAP Kinase Kinase Inhibitor on Activation and Translocation of MAP Kinase to the Nucleus with bFGF}

We examined the localization of MAP kinase in cultured astrocytes following treatment with bFGF and PD098059. MAP kinase was exclusively localized in the cytosol of untreated astrocytes (Fig. $3 \mathrm{~A})$. Strong immunostaining was observed in the nucleus and the area surrounding the nucleus in astrocytes stimulated with $100 \mathrm{ng} / \mathrm{ml}$ bFGF (Fig. $3 \mathrm{~B})$. The bFGF-induced increase in nuclear immunoreactivity of MAP kinase was totally abolished by treatment with bFGF plus PD098059 (Fig. 3C). These findings demonstrate that PD098059 interferes with bFGF stimulated activation and translocation of MAP kinase from the cytosol to the nucleus. The blockade of the translocation is correlated with inhibition of both MAP kinase activation and $\mathrm{C} / \mathrm{EBP} \delta$ phosphorylation.

\section{Effects of dbcAMP on Phosphorylation of $C / E B P \delta$ by Stimulation with $b F G F$}

We previously reported that dbcAMP inhibited basal MAP kinase activity in cultured astrocytes as well as MAP kinase activity stimulated by bFGF (27). Therefore, we examined whether dbcAMP inhibits phosphorylation of C/EBP $\delta$.

dbcAMP alone did not stimulate phosphoryla- 

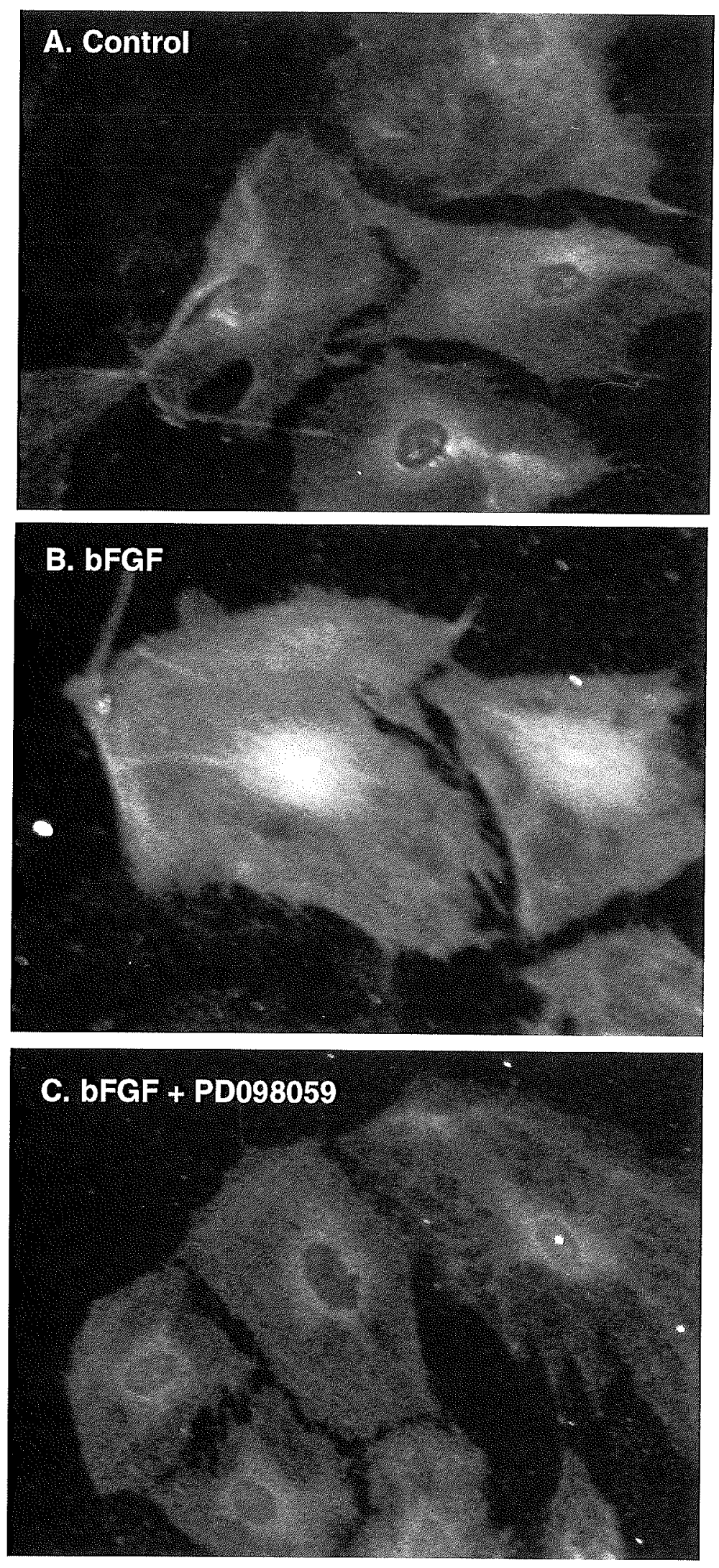

Fig. 3 


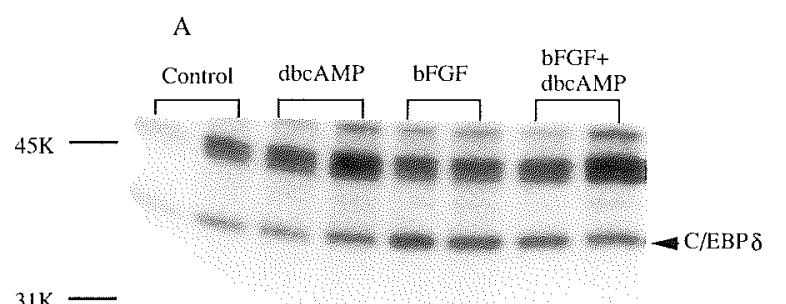

$31 \mathrm{~K}-$

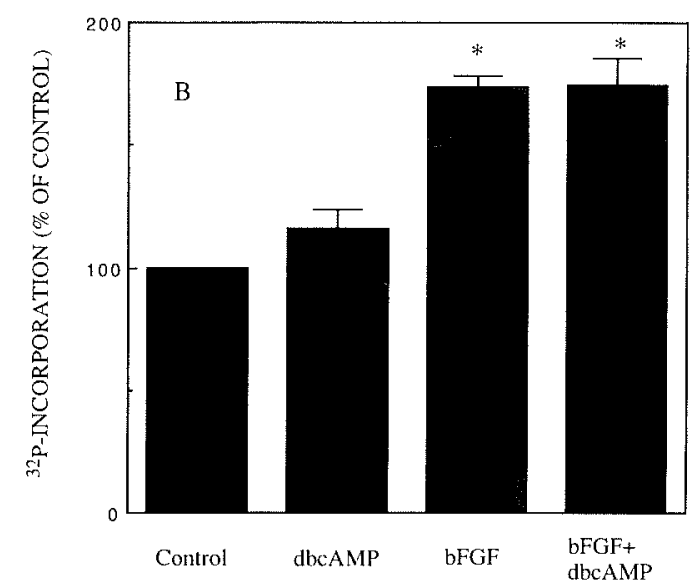

Fig. 4 Effects of dbcAMP on phosphorylation of $\mathrm{C} / \mathrm{EBP} \delta$ induced by bFGF in cultured astrocytes. Cultured astrocytes were incubated in serum-free medium for $24 \mathrm{~h}$ and labeled with $\left[{ }^{32} \mathrm{P}\right]$ orthophosphate for $5 \mathrm{~h}$ as in Fig. 1. The cells were preincubated without or with dbcAMP (1 mM) in $\mathrm{KRH}$ for $15 \mathrm{~min}$, and incubated without (control) or with dbcAMP (1 mM), bFGF (100 $\mathrm{ng} / \mathrm{ml}$ ) or bFGF plus dbcAMP for $60 \mathrm{~min}$. After incubation, the medium was aspirated and the cells were frozen in liquid $\mathrm{N}_{2}$. The cells were then scraped and homogenized with buffer. Triton X-100-soluble fractions were subjected to immunoprecipitation with the anti$\mathrm{C} / \mathrm{EBP} \delta$ antiboby. A; Phosphorylated $\mathrm{C} / \mathrm{EBP} \delta$ was immunoprecipitated with the anti-C/EBP $\delta$ antibody (5 $\mu \mathrm{g}$ ) and analyzed by SDS-PAGE, followed by autoradiography. $\mathrm{B}:{ }^{32} \mathrm{P}$-incorporation into $\mathrm{C} / \mathrm{EBP} \delta$ was determined by a Bio-Imaging analyzer (model BA100) and expressed as a percentage of control. Values are means $\pm \mathrm{SE}(\mathrm{n}=7) . *, P<0.05$, versus the control

Fig. 3 Translocation of MAP kinase by treatment with bFGF and its inhibition with PD098059. Cultured astrocytes were incubated in serum-free medium for $24 \mathrm{~h}$. The cells were preincubated in KRH for $15 \mathrm{~min}$, or with PD098059 $(50 \mu \mathrm{M})$ in $\mathrm{KRH}$ for $50 \mathrm{~min}$, and incubated without (control) (A) or with bFGF (100 ng/ml) (B) or bFGF plus PD098059 (C) for $60 \mathrm{~min}$. The cells were fixed in cold methanol, followed by treatment with $0.01 \%$ Triton-X. Fixed cells were incubated with the anti-active MAP kinase antibody and processed for indirect immunofluorescence. $\times 200$ tion of C/EBP $\delta$ in cultured astrocytes (Fig. 4), nor did it have a significant effect on bFGF stimulated phosphorylation of C/EBP $\delta$ (Fig. 4).

To understand discrepancies between the present and previous (27) reports, the effect of dbcAMP on the level of $\mathrm{C} / \mathrm{EBP} \delta$ protein was examined (Fig. 5). dbcAMP increased the level of $\mathrm{C} / \mathrm{EBP} \delta$ protein, while bFGF did not (Fig. 5B), suggesting that dbcAMP stimulates protein synthesis of $\mathrm{C} / \mathrm{EBP} \delta$. Addition of bFGF plus dbcAMP increased significantly the levels of $\mathrm{C} / \mathrm{EBP} \delta$ protein over control, but to a lesser degree than did dbcAMP alone.

Taken together with above results, dbcAMP was assumed to decrease phosphorylation of C/EBP $\delta$ by inhibition of MAP kinase. However, the level of $\mathrm{C} / \mathrm{EBP} \delta$ protein increased following treatment with dbcAMP. Thus, inhibition of phosphorylation of $\mathrm{C} / \mathrm{EBP} \delta$ was not apparently observed.

\section{Effects of Inhibitors on Phosphorylation of $C / E B P \delta$}

To identify kinases involved in phosphorylation of $\mathrm{C} / \mathrm{EBP} \delta$, the effects of inhibitors such as KN93 and calphostin $\mathrm{C}$ were examined. KN93, a specific inhibitor of CaM kinase II, had no effect on phosphorylation of $\mathrm{C} / \mathrm{EBP} \delta$ by stimulation with bFGF (Fig. 6). Similar results were obtained with calphostin $\mathrm{C}$, a specific inhibitor of protein kinase C. As shown in Fig. 7, calphostin $\mathrm{C}$ alone and together with bFGF had no inhibitory effect on phosphorylation of $\mathrm{C} / \mathrm{EBP} \delta$.

These results indicate that CaM kinase II and protein kinase $\mathrm{C}$ are not involved in phosphorylation of $\mathrm{C} / \mathrm{EBP} \delta$.

\section{Effects of bFGF Treatment on DNA-Binding Activity}

We examined effects of bFGF on DNA-binding activities of C/EBP family members in cultured astrocytes by gel mobility shift assay. After incubation without or with bFGF or bFGF plus PD098059 for $60 \mathrm{~min}$, nuclear extracts from the astrocytes were prepared. Following exposure to bFGF, the binding activities of C/EBPs apparently increased, and two complexes, $\mathrm{C}-1$ and $\mathrm{C}-2$, were observed (Fig. 8A). Following the exposure to bFGF plus PD098059, the binding activities of C/EBPs decreased in both complexes (Fig. 8, A and $\mathrm{B}$ ). The specificity of the DNA-protein complexes $\mathrm{C}-1$ and $\mathrm{C}-2$ was confirmed by competition with a nonlabeled homologous oligonucleotide 

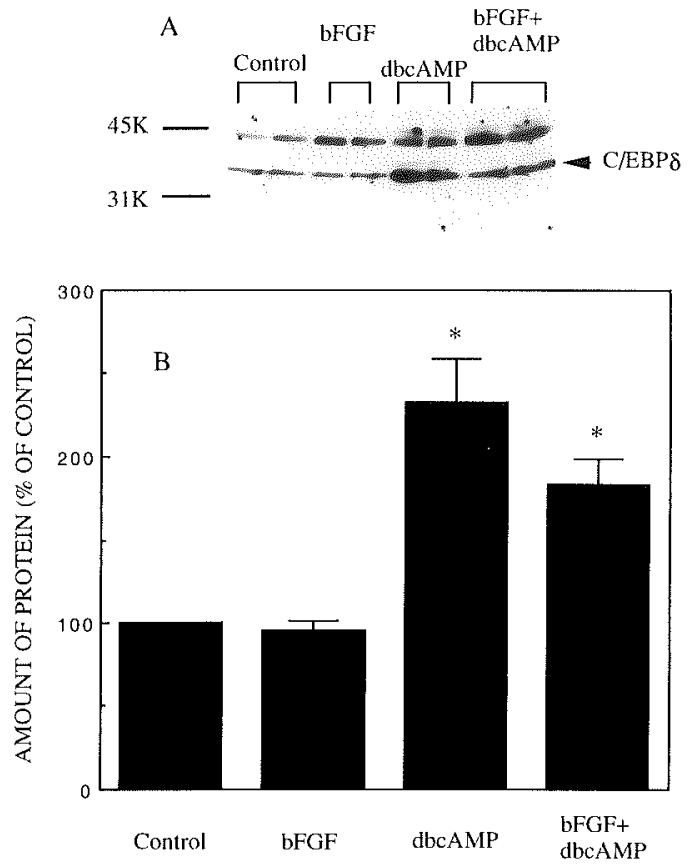

Fig. 5 Effects of bFGF and dbcAMP on protein levels of $\mathrm{C} / \mathrm{EBP} \delta$ in cultured astrocytes. Cultured astrocytes were incubated in serum-free medium for $24 \mathrm{~h}$. The cells were preincubated without or with dbcAMP (1 $\mathrm{mM}$ ) in $\mathrm{KRH}$ for $15 \mathrm{~min}$, and incubated without (control) or with bFGF $(100 \mathrm{ng} / \mathrm{ml})$, dbcAMP $(1 \mathrm{mM})$ or bFGF plus dbcAMP for $60 \mathrm{~min}$. A: Immunoblot analysis was carried out with the anti-C/EBP $\delta$ antibody. B: The relative amount of $\mathrm{C} / \mathrm{EBP} \delta$ on the autoradiograph was determined by a Bio-Imaging analyzer (model BA100) and expressed as a percentage of control. Values are means $\pm \mathrm{SE}(\mathrm{n}=5)$. ${ }^{*}, P<0.05$, versus the control

(Fig. 8A). Treatment of the DNA-protein complexes with anti-C/EBP $\beta$ or C/EBP $\delta$ antibody led to an apparent supershift of the complexes with a concomitant decrease in the $\mathrm{C}-1$ and $\mathrm{C}-2$ bands (Fig. $8 \mathrm{~A})$. The addition of the anti-C/EBP $\beta$ antibody decreased the intensity of the $\mathrm{C}-1$ complex stronger than the $\mathrm{C}-2$ complex (Fig. 8A, lane 6), while the $\mathrm{C}-1$ and $\mathrm{C}-2$ complexes both diminished by addition of the C/EBP $\delta$ antibody (Fig. 8A, lane 7). These results suggest that $\mathrm{C}-1$ and $\mathrm{C}-2$ complexes induced in response to bFGF are heterooligomers containing at least two proteins each related to $\mathrm{C} / \mathrm{EBP} \beta$ and $\mathrm{C} / \mathrm{EBP} \delta$ and that the phosphorylation of $\mathrm{C} / \mathrm{EBP} \delta$ with $\mathrm{bFGF}$ increases DNAbinding activity.

The present study showed that stimulation of astrocytes with $\mathrm{bFGF}$ increases phosphorylation of $\mathrm{C} / \mathrm{EBP} \delta$, but not $\mathrm{C} / \mathrm{EBP} \beta$, by MAP kinase. Furthermore, phosphorylation of $\mathrm{C} / \mathrm{EBP} \delta$ increased its
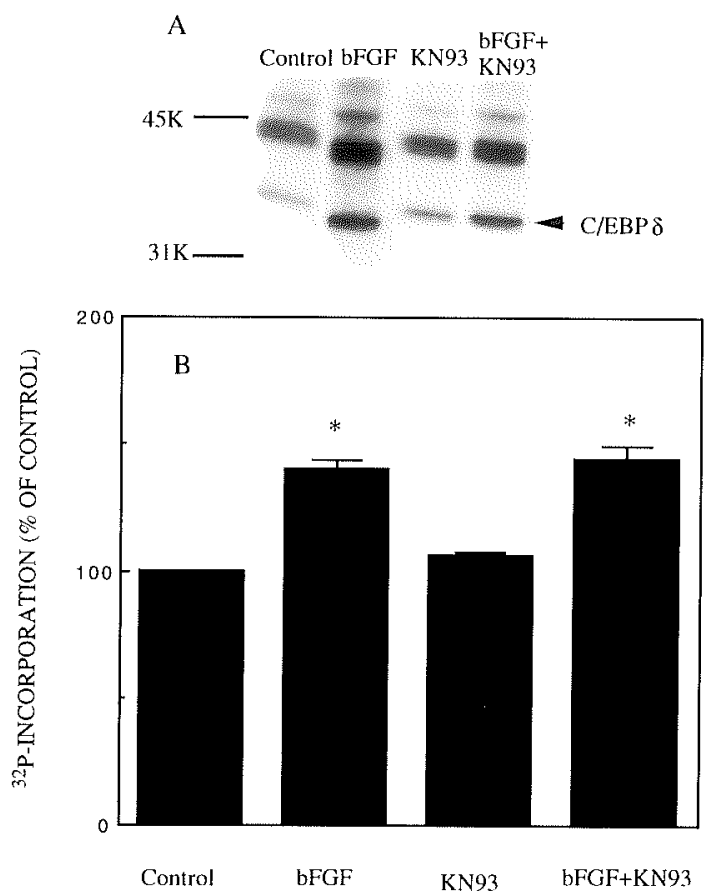

Fig. 6 Effects of KN93, an inhibitor of CaM kinase II, on phosphorylation of C/EBP $\delta$ induced by bFGF. Cultured astrocytes were incubated in serum-free medium for $24 \mathrm{~h}$ and labeled with [ ${ }^{32} \mathrm{P}$ ]orthophosphate for $5 \mathrm{~h}$ as in Fig. 1. The cells were preincubated without or with KN93 $(20 \mu \mathrm{M})$ in $\mathrm{KRH}$ for $15 \mathrm{~min}$, and incubated without (control) or with bFGF $(100 \mathrm{ng} / \mathrm{ml}), \mathrm{KN} 93(20 \mu \mathrm{M})$ or bFGF plus KN93 for $60 \mathrm{~min}$. After incubation, the medium was aspirated and the cells were frozen in liquid $\mathrm{N}_{2}$. The cells were then scraped and homogenized with buffer. Triton X-100-soluble fractions were subjected to immunoprecipitation with the anti-C/EBP $\delta$ antibody. A: Phosphorylated C/EBP $\delta$ was immunoprecipitated with the anti-C/EBP $\delta$ antibody $(5 \mu \mathrm{g})$ and analyzed by SDS-PAGE, followed by autoradiography. B: ${ }^{32} \mathrm{P}$-Incorporation into C/EBP $\delta$ was determined by a Bio-Imaging analyzer (model BA100) and expressed as a percentage of control. Values are means $\pm S E(n=4)$. $*, P<0.05$, versus the control

DNA-binding activities. A report by Wegner et al. (52) shows increased transcriptional activity of C/EBP $\beta$ following glutamate stimulation; here we show that $\mathrm{bFGF}$ increases DNA binding of $\mathrm{C} / \mathrm{EBP} \delta$, which may in turn result in increased transcriptional activity. Such activities may be involved in functions of astrocytes, such as proliferation.

This research was supported in part by grants-in-aid for Scientific Research and for Scientific Research on Priority Areas from the Ministry of Education, Science, 
A
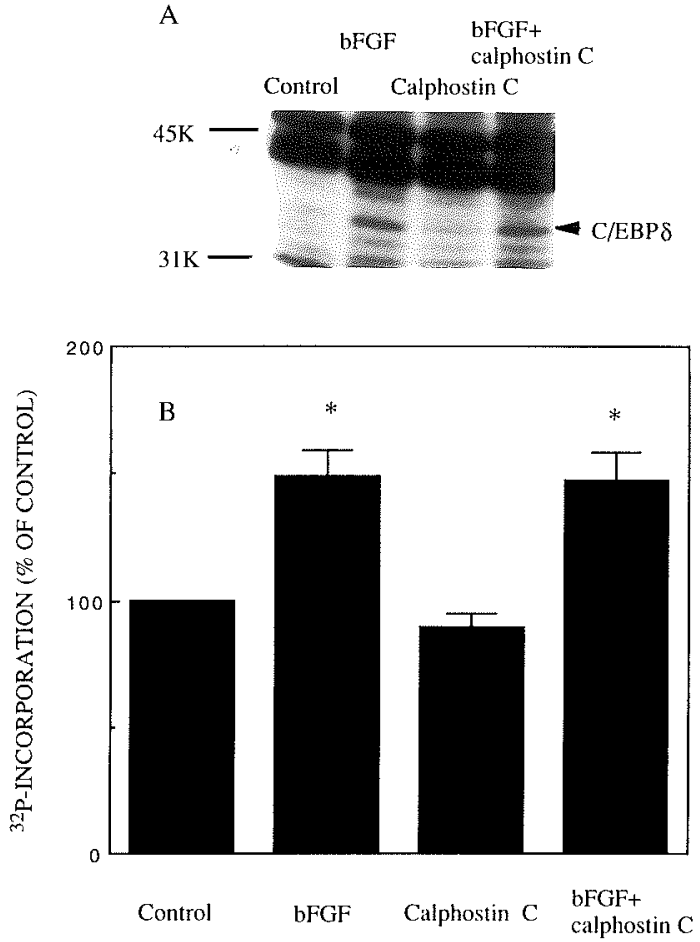

Fig. 7 Effects of calphostin C, an inhibitor of protein kinase $\mathrm{C}$, on phosphorylation of $\mathrm{C} / \mathrm{EBP} \delta$ induced by bFGF. Cultured astrocytes were incubated in serum-free medium for $24 \mathrm{~h}$ and labeled with $\left[{ }^{32} \mathrm{P}\right]$ orthophosphate for $5 \mathrm{~h}$ as in Fig. 1. The cells were preincubated without or with calphostin $\mathrm{C}(100 \mathrm{nM})$ in $\mathrm{KRH}$ for $15 \mathrm{~min}$, and incubated without (control) or with bFGF $(100 \mathrm{ng} / \mathrm{ml}$ ), calphostin C (100 $\mathrm{nM})$ or bFGF plus calphostin C for 60 min. After incubation, the medium was aspirated and the cells were frozen in liquid $\mathrm{N}_{2}$. The cells were then scraped and homogenized with buffer. Triton X-100-soluble fractions were subjected to immunoprecipitation with the anti-C/EBP $\delta$ antibody. A: Phosphorylated $\mathrm{C} / \mathrm{EBP} \delta$ was immunoprecipitated with the anti-C/EBP $\delta$ antibody $(5 \mu \mathrm{g})$ and analyzed by SDS-PAGE, followed by autoradiography. $\mathrm{B}:{ }^{32} \mathrm{P}$-Incorporation into $\mathrm{C} / \mathrm{EBP} \delta$ was determined by a Bio-Imaging analyzer (model BA100) and expressed as a percentage of control. Values are means $\pm \mathrm{SE}(\mathrm{n}=4)$. *, $P<0.05$, versus the control

Sports and Culture, and by the Research Grant from the Human Frontier Science Program.

Received 11 December 1997; and accepted 26 December 1997

\section{REFERENCES}

1. Akira S., Isshiki H., Sugita T., Tanabe O., Kinoshita S., Nishio Y., Nakajima T., Hirano T. and Kishimoto T.
A

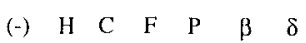
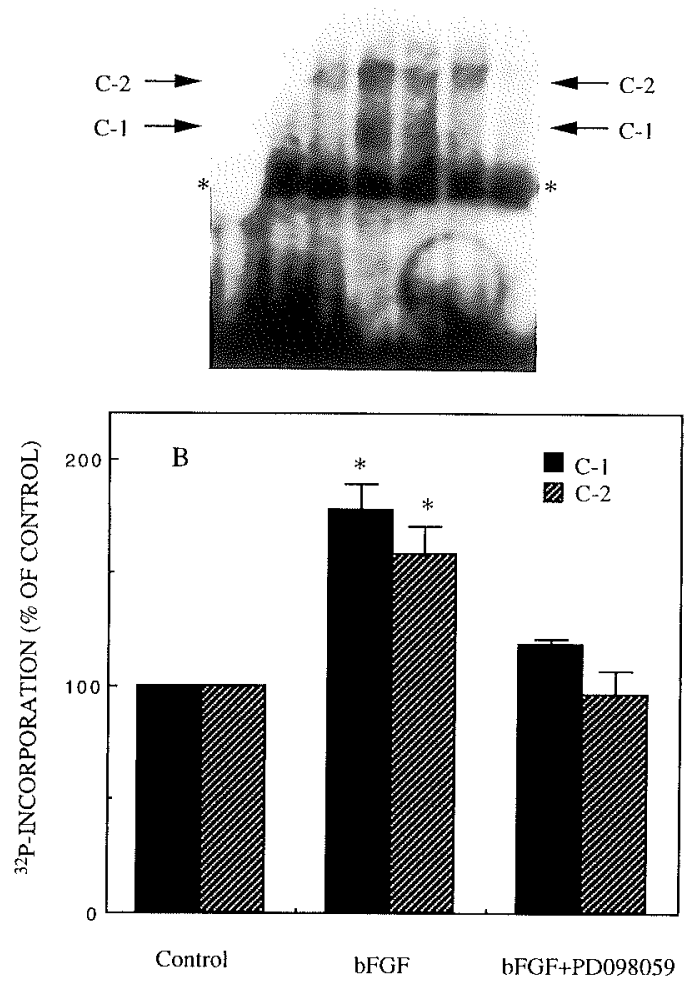

Fig. 8 Changes in DNA-binding activities of C/EBP family members following treatment with bFGF. Cultured astrocytes were incubated in serum-free medium for $24 \mathrm{~h}$. A: The cells were preincubated in $\mathrm{KRH}$ or with PD098059 $(50 \mu \mathrm{M})$ in $\mathrm{KRH}$ for $15 \mathrm{~min}$, and incubated without (control) (C) or with bFGF $(100 \mathrm{ng} / \mathrm{ml}$ ) (F) or bFGF plus PD098059 (P) for $60 \mathrm{~min}$. The cells were collected and nuclear extracts were prepared. A gel-shift assay using a ${ }^{32} \mathrm{P}$-labeled oligonucleotide probe was performed as described in Materials and Methods. Protein-DNA complexes were separated on a $5 \%$ nondenaturing polyacrylamide gel, followed by autoradiography. $(-)$ denotes ${ }^{32} \mathrm{P}$-labeled probe in the absence of nuclear extract, and $(\mathrm{H})$ indicates the addition of a 1,000 -fold excess of unlabeled probe used as a competior. $(\beta)$ and $(\delta)$ indicate binding assays done in the presence of $\mathrm{C} / \mathrm{EBP} \beta$ antibody $(3 \mu \mathrm{g})$ and $\mathrm{C} / \mathrm{EBP} \delta$ antibody $(3 \mu \mathrm{g})$, respectively. $\mathrm{C}-1$ and $\mathrm{C}-2$ mark specific complexes which could be eliminated by competing oligonucleotide probe; the asterisk marks a nonspecific complex. B: ${ }^{32} \mathrm{P}$-Incorporation into the complexes $\mathrm{C}-1$ and $\mathrm{C}-2$ was determined by a Bio-Imaging analyzer (model BA 100) and expressed as a percentage of control. Values are means $\pm \mathrm{SE}(\mathrm{n}=4)$. ${ }^{*}, P<0.05$, versus the control 
(1990) A nuclear factor for IL-6 expression (NF-IL6) is a member of a C/EBP family. EMBO J. 9, 1897-1906

2. Alam T., An M. R. and Papaconstantinou J. (1992) Differential expression of three C/EBP isoforms in multiple tissues during the acute phase response. J. Biol. Chem. 267, $5021-5024$

3. Alberini C. M., Ghirardi M., Metz R. and Kandel E. R. (1994) C/EBP is an immediate-early gene required for the consolidation of long-term facilitation in Aplysia. Cell 76, 1099-1114

4. Alessi D. R., Cuenda A., Cohen P., Dudley D. T. and SAltiel A. R. (1995) PD098059 is a specific inhibitor of the activation of mitogen-activated protein kinase kinase in vitro and in vivo. J. Biol. Chem. 270, 27489-27494

5. BAIRD A. (1994) Fibroblast growth factors: activities and significance of non-neurotophin neurotrophic growth factors. Curr: Opin. Neurobiol. 4, 78-86

6. Bhat N. R., Zhang P. and Hoban E. L. (1995) Thrombin activates mitogen-activated protein kinase in primary astrocyte cultures. J. Cell. Physiol. 165, 417-424

7. BradFord M. M. (1976) A rapid and sensitive method for the quantitation of microgram quantities of protein utilizing the principle of protein-dye binding. Anal. Biochem. 72, 248-254

8. Cardinaux J. R. and Magistretti P. J. (1996) Vasoactive intestinal peptide, pituitary adenylate cyclase-activating peptide, and noradrenaline induce the transcription factor CCAAT/enhancer binding protein (C/EBP) $\beta$ and C/EBP $\delta$ in mouse cortical astrocytes: involvement in CAMP-regulated glycogen metabolism. J. Neurosci. 16, 919-929

9. Chen P. L., Rilley D. J., Chen-Kiang S. and Lee W. H. (1996) Retinoblastoma protein directly interacts with and activates the transcription factor NF-IL6. Proc. Natl. Acad. Sci. USA 93, 465-469

10. Chowdhury S., Gotoh T., Mori M. and Takiguchi M. (1996) CCAAT/enhancer-binding protein $\beta$ binds and activates while hepatocyte nuclear factor-4 (HNF-4) does not bind but represses the liver-type arginase promoter, Eur: $J$. Biochem. 236, 500-509

11. Clarkson R. W. E., Chen C. M., Harrison S., Wells C., Muscat G. E. O. and Waters M. J. (1995) Early responses of transactivating factors to growth hormone in preadipocytes: differential regulation of CCAAT/enhancer binding protein $\beta(\mathrm{C} / \mathrm{EBP} \beta)$ and $\mathrm{C} / \mathrm{EBP} \delta$. Mol. Endocrinol. 9, $108-120$

12. Condorelli D. F., Dell'albani P., Amico C., Kaczmarek L., Nicoletti F., Lukasiuk K. and Stella A. M. G. (1993) Induction of primary response genes by excitatory amino acid receptor agonists in primary astroglial cultures. J. Neurochem. 60, 877-885

13. Dent P., Haser W., Haystead T. A. J., Vincent L. A., Roberts T. M. and Sturgill T. W. (1992) Activation of mitogen-activated protein kinase kinase by $\mathrm{v}$-Raf in NIH 3 T3 cells and in vitro. Science 257, 1404-1407

14. Descombes P. and Schibler V. (1991) A liver-enriched transcriptional activator protein, LAP, and a transcriptional inhibitory protein, LIP, are translated from the same mRNA. Cell 67, 569-579

15. Faber-Elman A., Solomon A., Abraham J. A., MARIKovSKY M. and SCHWARTZ M. (1996) Involvement of wound-associated factor in rat brain astrocyte migratory response to axonal injury: in vitro stimulation. J. Clin. Invest. 97, 162-171
16. Fukunaga K, Muller D. and MiYamoto E. (1995) Increased phosphorylation of $\mathrm{Ca}^{2+} /$ calmodulin-dependent protein kinase II and its endogenous substrates in the induction of long-term potentiation. J. Biol. Chem. 270, $6119-6124$

17. Fukunaga K., Muller D. and Miyamoto E. (1996) CaM kinase II in long-term potentiation. Neurochem. Int. 28, 343-358

18. Fukunaga K., Rich D. P. and Soderling T. R. (1989) Generation of the $\mathrm{Ca}^{2+}$-independent form of the $\mathrm{Ca}^{2+} /$ calmodulin-dependent protein kinase II in cerebellar granule cells. J. Biol. Chem. 264, 21830-21838

19 Fukunaga K., Soderling T. R. and Miyamoto E. (1992) Activation of $\mathrm{Ca}^{2+} / \mathrm{calmodulin}$-dependent protein kinase II and protein kinase $\mathrm{C}$ by glutamate in rat hippocampal neurons. J. Biol. Chem. 267, 22527-22533

20. Gately S. B. A., Soff G. A. and Brem S. (1995) The potential role of basic fibroblast growth factor in the transformation of cultured primary human fetal astrocytes and the proliferation of human glioma (U-87) cells. Neurosurgery 37, 723-732

21. Gomes-Pinilla F., Miller S., Choi J. and Cotman C. W. (1997) Heparan sulfate potentiates the autocrine action of basic fibroblast growth factor in astrocytes: an in vivo and in vitro study. Neuroscience 76, 137-145

22. Gotoh Y., Masuyama N., Suzuki A., Ueno N. and NishiDA E. (1995) Involvement of the MAP kinase cascade in Xenopus mesoderm induction. EMBO J. 14, 2491-2498

23. Howe L. R., Leevers S. J., Gomez N., Nakielny S., Cohen P. and Marshall C. J. (1992) Activation of the MAP kinase pathway by the protein kinase raf. Cell 71, 335-342

24. Kageyama R., Sasaki Y. and Nakanishi S. (1991) Molecular characterization of transcription factors that bind to the cAMP-responsive region of the substance P precursor gene. J. Biol. Chem. 266, 15525-15531

25. Kinoshita S., Akira S. and Kishimoto T. (1992) A member of the C/EBP family, NF-IL6 $\beta$, forms a heterodimer and transcriptionally synergizes with NF-IL6. Proc. Natl. Acad. Sci. USA 89, 1473-1476

26. Kurino M., Fukunaga K., Ushio Y. and Miyamoto E. (1995) Activation of mitogen-activated protein kinase in cultured rat hippocampal neurons by stimulation of glutamate receptors. J. Neurochem. 65, 1282-1289

27. Kurino M., Fukunaga K., Ushio Y. and Miyamoto E. (1996) Cyclic AMP inhibits activation of mitogen-activated protein kinase and cell proliferation in response to growth factors in cultured rat cortical astrocytes. J. Neurochem. 67, $2245-2255$

28. Kyriakis J. M., ApP H., Zhang X. F., Banerjee P., Brautigan D. L., Rapp U. R. and Avruch J. (1992) Raf-1 activates MAP kinase kinase. Nature 358, 417-421

29. LAMB P. and McKnight S. L. (1991) Diversity and specificity in transcriptional regulation: the benefits of heterotypic dimerization. Trends Biochem. Sci. 16, 417-422

30. Landschulz W. H., Johnson P. F. and McKnight S. L. (1989) The DNA binding domain of the rat liver nuclear protein C/EBP is bipartite. Science 243, 1681-1688

31. Mahoney C. W., Shuman J., McKnight S. L., Chen H. C. and Huang K. P. (1992) Phosphorylation of CCAATenhancer binding protein by protein kinase $\mathrm{C}$ attenuates siteselective DNA binding. J. Biol. Chem. 267, 19396-19403

32. MCCarthy K. D. and De Vellis J. (1980) Preparation of 
separate astroglial and oligodendroglial cell cultures from rat cerebral tissue. J. Cell Biol. 85, 890-902

33. MeTZ R. and ZIFF E. (1991) cAMP stimulates the C/EBPrelated transcription factor $\gamma$ NF-IL6 to translocate to the nucleus and induce c-fos transcription. Gene. Develop. 5, $1754-1766$

34. Nakajima T., Kinoshita S., Sasagawa T., Sasaki K., Naruto M., Kishimoto T. and Akira S. (1993) Phosphorylation at threonine- 235 by a ras-dependent mitogen-activated protein kinase cascade is essential for transcription factor NF-IL6. Proc. Natl. Acad. Sci. USA 90, 207-211

35. Osada S., Yamamoto H., Nishihara T. and Imagawa M. (1996) DNA binding specificity of the CCAAT/enhancerbinding protein transcription factor family. J. Biol. Chem. 271, 3891-3896

36. Pang L., Sawada T., Decker S. J. and Saltiel A. R. (1995) Inhibition of MAP kinase kinase blocks the differentiation of PC-12 cells induced by nerve growth factor. $J$. Biol. Chem. 270, 13585-13588

37. Pechan P. A., Chowdhury K., Gerdes W. and Seifert W. (1993) Glutamate induces the growth factors NGF, bFGF, the receptor FGF-R1 and c-fos mRNA expression in rat astrocyte culture. Neurosci. Lett. 153, 111-114

38. Perraud F., Besnard F., Pettmann B., Sensenbrenner M. and LABourdette M. (1988) Effects of acidic and basic fibroblast growth factors ( $\mathrm{aFGF}$ and $\mathrm{bFGF}$ ) on the proliferation and the glutamate synthetase expression of rat astroblast in culture. Glia 1, 124-131

39. Poli V., Mancini F. P. and Cortese R. (1990) IL-6DBP, a nuclear protein involved in interleukin- 6 signal transduction, defines a new family of leucine zipper proteins related to C/EBP. Cell 63, 643-653

40. Raff M. C., Abney E. R., Cohen J., Lindsay R. and NoBle M. (1983) Two types of astrocytes in cultures of developing rat white matter: differences in morphology, surface gangliosides, and growth characteristics. J. Neurosci. 3, $1289-1300$

41. RaY A. and RAY B. K. (1994) Serum amyloid A gene expression under acute-phase conditions involves participation of inducible C/EBP $\beta$ and $\mathrm{C} / \mathrm{EBP} \delta$ and their activation by phosphorylation. Mol. Cell. Biol. 14, 4324-4332

42. RAY B. K. and RAY A. (1994) Expression of the gene encoding $\alpha 1$-acid glycoprotein in rabbit liver under acutephase conditions involves induction and activation of $\beta$ and $\delta$ CCAAT-enhancer-binding proteins. Eur. J. Biochem. 222, $891-900$

43. Roman C., Platero J. S., Shuman J. and Calame K. (1990) Ig/EBP-1: a ubiquitously expressed immunoglobulin enhancer binding protein that is similar to C/EBP and heterodimerizes with C/EBP. Gene. Develop. 4, 1404-1415

44. Ron D. and HABENER J. F. (1992) CHOP, a novel develop- mentally regulated nuclear protein that dimerizes with transcription factors C/EBP and LAP and functions as a dominant-negative inhibitor of gene transcription. Gene. Develop. 6, 439-453

45. Sano M., Kohno M. and Iwanaga M. (1995) The activation and nuclear translocation of extracellular signal-regulated kinases (ERK-1 and ERK-2) appear not to be required for elongation of neurites in PC12D cells. Brain Res. $\mathbf{6 8 8}$, $213-218$

46. Temple S. and Qian X. (1995) bFGF, Neurotrophins, and the control of cortical neurogenesis. Neuron 15, 249-252

47. Trautwein C., Caelles C., Geer V. D. P., Hunter T., Karin M. and ChoJKIER M. (1993) Transactivation by NFIL6/LAP is enhanced by phosphorylation of its activation domain. Nature 364, 544-547

48. Trautwein C., Geer V. D. P., Karin M., Hunter T. and Chojkier M. (1994) Protein kinase A and C site-specific phosphorylation of LAP (NF-IL6) modulate its binding affinity to DNA recognition elements. J. Clin. Invest. 93, 2554-2561

49. Trautwein C., Walker D. L., Plumpe J. and Manns M. P. (1995) Transactivation of LAP/NF-IL6 is mediated by an acidic domain in the N-terminal part of the protein. J. Biol. Chem. 270, 15130-15136

50. Vinson C. R. and McKnight S. L. (1989) Scissors-grip model for DNA recognition by a family of leucine zipper proteins. Science 246, 911-916

51. WALICKE P. A. (1988) Basic and acidic fibroblast growth factors have trophic effects on neurons from multiple CNS regions. J. Neurosci. 87, 2618-2627

52. Wegner M., CaO Z. and Rosenfeld M. G. (1992) Calcium-regulated phosphorylation within the leucine zipper of C/EBP $\beta$. Science 256, 370-373

53. Williams S. C., Cantwell C. A. and Johnson P. F. (1991) A family of C/EBP-related proteins capable of forming covalently linked leucine zipper dimers in vitro. Gene. Develop. 5, 1553-1567

54. Yano S., Fukunaga K., Takiguchi M., Ushio Y., Mori M. and MiYamoto E. (1996) Regulation of CCAAT/ enhancer-binding protein family members by stimulation of glutamate receptors in cultured rat cortical astrocytes. $J$. Biol. Chem. 271, 23520-23527

55. Yano S., Fukunaga K., Ushio Y. and Miyamoto E. (1994) Activation of $\mathrm{Ca}^{2+} /$ calmodulin-dependent protein kinase II and phosphorylation of intermediate filament protein by stimulation of glutamate receptor in cultured rat cortical astrocytes. J. Biol. Chem. 269, 5428-5439

56. Yen W. C., Cao Z., Classon M. and McKnight S. L. (1994) Cascade regulation of terminal adipocyte differentiation by three members of the C/EBP family of leucine zipper proteins. Gene. Develop. 9, 168-181 